Journal of Southeast Asian

\title{
Txoj Kev Ntshiab: Hmong American undergraduates' perceptions of intellectual phoniness and psychosociocultural persistence decisions
}

Jenjee T. Sengkhammee

Pa Her

University of Wisconsin - Madison, her1@wisc.edu

Alberta M. Gloria

Mariko M. Lin

Betty Jo Thao

See next page for additional authors

Follow this and additional works at: https://docs.lib.purdue.edu/jsaaea

Part of the Higher Education Commons, and the Student Counseling and Personnel Services Commons

\section{Recommended Citation}

Sengkhammee, Jenjee T.; Her, Pa; Gloria, Alberta M.; Lin, Mariko M.; Thao, Betty Jo; Cabinte, Desiree; and Aroonsavath, Linda (2017) "Txoj Kev Ntshiab: Hmong American undergraduates' perceptions of intellectual phoniness and psychosociocultural persistence decisions," Journal of Southeast Asian American Education and Advancement. Vol. 12 : Iss. 1, Article 1.

DOI: $10.7771 / 2153-8999.1139$

Available at: https://docs.lib.purdue.edu/jsaaea/vol12/iss1/1

This document has been made available through Purdue e-Pubs, a service of the Purdue University Libraries. Please contact epubs@purdue.edu for additional information.

This is an Open Access journal. This means that it uses a funding model that does not charge readers or their institutions for access. Readers may freely read, download, copy, distribute, print, search, or link to the full texts of articles. This journal is covered under the CC BY-NC-ND license. 


\section{Txoj Kev Ntshiab: Hmong American undergraduates' perceptions of intellectual phoniness and psychosociocultural persistence decisions}

\section{Cover Page Footnote}

Author's Notes. "Txoj kev ntshiab" in the Hmong language means "the new road" or the "clear road" referring to the new "life" and educational opportunities in the U.S. available to Hmong immigrants. The authors acknowledge the contributions of Asia Thao and Sheeyee Chang. Jenjee T. Sengkhammee is a licensed psychologist in private practice. Mariko M. Lin is a staff psychologist at Oregon State University. $\mathrm{Pa} \mathrm{Her}$ is a doctoral student, Linda Aroonsavath is a doctoral candidate, and Alberta M. Gloria, is a Professor in the Department of Counseling Psychology at the University of Wisconsin-Madison. Desiree Cabinte is a licensed psychologist at the Department of Veteran Affairs at Pacific Islands Health Care System. Betty Jo Thao was a Masters student in the Department of Educational Policy Studies.

Correspondence concerning this article should be addressed to Pa Her, Department of Counseling Psychology, University of Wisconsin-Madison, 335 Education Building - 1000 Bascom Mall, Madison, WI 53706-1398 (email: her1@wisc.edu).

\section{Authors}

Jenjee T. Sengkhammee, Pa Her, Alberta M. Gloria, Mariko M. Lin, Betty Jo Thao, Desiree Cabinte, and Linda Aroonsavath 


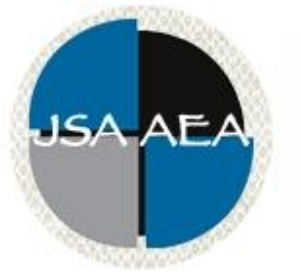

Vol. 12 Iss. 1 (2017)

\section{Journal of Southeast Asian American Education and Advancement}

WWW.JSAAEA.org

\title{
Txoj Kev Ntshiab: Hmong American Undergraduates' Perceptions of Intellectual Phoniness and Psychosociocultural Persistence Decisions
}

\author{
Jenjee T. Sengkhammee \\ University of Wisconsin-Madison \\ Pa Her \\ University of Wisconsin-Madison \\ Alberta M. Gloria \\ University of Wisconsin-Madison \\ Mariko M. Lin \\ University of Oregon \\ With \\ Betty Jo Thao, Desiree Cabinte, \& Linda Aroonsavath \\ University of Wisconsin-Madison
}

\begin{abstract}
Examining the educational experiences of 103 Hmong American undergraduates, gender and class standing differences emerged using a psychosociocultural approach. Females reported increased perceptions of family and friend support and greater cultural congruity in the university environment than males. Lower-division students indicated greater perceptions of social support from family, greater cultural congruity, and lower self-esteem than upper-division students. Feelings of phoniness emerged as the most significant negative predictor of academic persistence decisions. Implications, limitations, and future research are discussed.
\end{abstract}

Keywords: Hmong Americans, undergraduates, academic persistence decisions, intellectual phoniness

\footnotetext{
(9)

SOMERIGHISRESEFNEDReaders are free to copy, display, and distribute this article, as long as the work is attributed to the author(s) and the Journal of Southeast Asian American Education \& Advancement, it is distributed for non-commercial purposes only, and no alteration or transformation is made in the work. More details of this Creative Commons license are available at http://creativecommons.org/licenses/by-nc-nd/3.0/. All other uses must be approved by the author(s) or JSAAEA.

Journal of Southeast Asian American Education \& Advancement, Vol. 12. Iss. 1. (2017) ISSN: 2153-8999
} 
As a fast-growing minority group in the U.S., $42 \%$ of Hmong Americans are less than 18 years of age, making them a young population navigating the education system (U.S. Census, 2013). Currently, nearly one-third (30\%) of the Hmong population has less than a high school education, with $11 \%$ holding a bachelor's degree and only $4 \%$ having earned a graduate or professional degree (U.S. Census, 2013; Xiong, 2012). Comparatively, the numbers of degrees conferred are lower than that of the U.S. population and lowest among the Asian American ethnic groups (excluding Pacific Islanders) (U.S. Census, 2013). As a rapidly growing young population, Hmong communities value and have the motivation to achieve educationally (Hutchinson, 1997; Ngo, 2013; Swartz, Lee \& Mortimer, 2003). Yet, as Hmong American students enter into higher education (Lee, 1997; Lor, 2008; Xiong \& Lam, 2013; Xiong \& Lee, 2011; Lin, Her, \& Gloria, 2015; Vue, 2013) little is known about their psychological, social, or cultural persistence processes, despite the educational disparities and their imminent presence within the educational system (U.S. Census, 2013). How self-perceptions, social supports, and cultural processes influence their decisions to persist academically is thus the study's focus.

\section{Hmong Cultural Values as Related to the Family and Education}

In understanding the educational experiences of Hmong American undergraduates, the importance of integrating their cultural and familial values is critical (Her \& Gloria, 2016) because family serves as an important biological and social structure in which relationships and roles are salient (Chiang, Fisher, Collins, \& Ting, 2015; Moua, 2003). For example, traditional Hmong families are patrilineal with distinct gender roles and responsibilities for males and females (Yang, 1997). Males are regarded as providers and protectors who are financially responsible for families, whereas women are charged with the maintenance of family (Moua, 2003). Despite traditional gendered norms, Hmong families encourage their children to pursue education as a means to support the family (Chiang et al., 2015; DePouw, 2003). It is evident that investigations of Hmong American undergraduates must include dimensionalized explorations by gender to understand accurately their educational experiences.

\section{Psychosociocultural Model of Academic Persistence}

The Psychosociocultural (PSC) framework, a holistic student development approach, was used in this study to explore Hmong American undergraduates' persistence processes. Developed as a meta-model, the PSC integrates and contextualizes emergent aspects of undergraduates' educational experiences within three equally salient dimensions: psychological, social, and cultural. The model emphasizes non-cognitive processes that influence students' educational experiences. Variables within each dimension vary based on the study population; however the dimensions are needed to gain a holistically- and culturally-based assessment of students' processes (Castellanos \& Gloria, 2007; Gloria \& Rodriguez, 2000). Empirically-validated with Asian American (Gloria \& Ho, 2003) and Hmong American undergraduates (Lin, Her, \& Gloria, 2015), the model provides the contextual lens to understand students' persistence processes. Given that theoretically-driven quantitatively-focused research on Hmong Americans in higher education is sparse, literature is included on Asian Americans and Southeast Asian American undergraduates. 


\section{Psychological Dimension: Self-Beliefs}

The psychological dimension represented Hmong American students self-beliefs within the educational context. As students' overall sense of self significantly predicts academic nonpersistence decisions (Solberg, O’Brien, Villarreal, Kennel, \& Davis, 1993), understanding one's sense of self-confidence and self-competence is warranted. For example, students' abilities to complete school tasks has been associated with academic nonpersistence decisions for Asian American (Gloria \& Ho, 2003) and Hmong American undergraduates (Lin et al., 2015). In particular, upper-division students reported higher confidence in their ability to complete college tasks than their lower-division peers (Lin et al., 2015). The authors noted that increased time in the university setting (based on class standing) added to increased academic efficacy.

In addition to feeling confident about college tasks, the degree to which students experience feelings of intellectual phoniness or impostors (Clance \& Imes, 1978) is common for many firstgeneration college and racial and ethnic minority students (Cokley, McLain, Enciso, \& Martinez, 2012; Gloria \& Segura-Herrera, 2004). The concept of intellectual phoniness has historically been examined for high-achieving women who did not experience internal success despite praise and support, as they often feared they would be discovered for being "intellectual impostors" (Clance \& Imes, 1978). For Hmong American undergraduates, Lin et al. (2015) reported that feelings of phoniness was the strongest negative predictor of nonpersistence decisions, which was also associated with a decreased perception of social support from friends.

\section{Social Dimension: Connections and Support}

How students view themselves can be buffered by their perceptions of social support to pursue higher education and related connections within their educational setting. In particular, support from key relationships (i.e., family, parents, and friends) has been evidenced with Asian American (Gloria \& Ho, 2003) and Hmong American undergraduates (Lin et al., 2015). For example, Asian American students perceived family as supportive, while simultaneously experiencing the support as pressure to excel (Osajima, 1991, 1995). Swartz et al. (2003) also found that parents and family members, despite their limited level of education, are influential as they concurrently provide support and pressure for Hmong American undergraduates. More recently, Her and Gloria (2016) found that Hmong parents' sense of self-efficacy was the strongest predictor of their parental encouragement for their undergraduate son or daughter. Understanding the complex nature of perceived familial support for Hmong American students' and its influence on their academic persistence decisions is increasingly important.

Another relevant source of support is from peers (e.g., friends and classmates), as increased support has been associated with academic competence and adjustment among Asian Americans (Chong, Huan, Yeo, \& Ang, 2006). For Hmong undergraduates, support from friends was also directly related to their academic nonpersistence decisions (Lin et al., 2015). In particular, peer connections and opportunities to develop needed social relationships (Delgado-Romero \& Hernandez, 2002) and cultural connections and understandings (Vue, 2013) occur through student organizations and groups, which in turn are linked to student persistence. 


\section{Cultural Dimension: Values and Fit}

The importance of cultural connection, maintenance, and validation is a salient dimension for racial and ethnic minority undergraduates within higher education (Gloria \& Castellanos, 2003; Museus, 2014). In particular, ethnic identity was positively related to increased cultural congruity, more positive perceptions of the university environment, and fewer nonpersistence decisions for Hmong American undergraduates (Lin et al., 2015). A related study of 101 Hmong American students revealed an orientation to both Hmong and American cultural values whereby the ability to employ a bicultural strategy (i.e., balancing of American and Hmong cultures) assisted their academic success (Bosher, 1997).

The way in which students' perceive the environment is directly related to their sense of cultural fit, and subsequent feeling within the environment context (Cokley et al., 2012; Gloria \& Castellanos, 2003; Ong, Burrow, Fuller-Rowell, Ja, \& Sue, 2013). For example, Bennett and Okinaka (1990) found that Asian American students who reported a negative quality of campus life had strong feelings of social alienation and dissatisfaction. Likewise, upper-division Hmong undergraduates, who had presumably spent more time within the educational context, perceived the university environment as less welcoming and more culturally incongruent than their lowerdivision counterparts (Lin et al., 2015).

As students experience negative campus events, cultural congruity (i.e., the fit of values between one's personal and environment) (Gloria \& Robinson Kurpuis, 1996) is lower for Asian American students (Gloria \& Ho, 2003). It is posited that lower congruity resulted from differing behaviors, beliefs, and values of students who often find their educational situations unwelcoming or incongruent (Gloria \& Pope-Davis, 1997). Supporting this notion, Gloria and Ho (2003) found that an increased sense of cultural congruity and positive perception of the university environment were related to higher self-efficacy and self-esteem for Asian American undergraduates; a cultural fit and connection within the university environment affects Asian American students' social adjustment and academic resilience (Suzuki, 1994).

\section{Study's Purpose}

The unique, collective, and contextualized educational experiences of undergraduates were explored holistically using a psychosociocultural approach (Gloria \& Rodriguez, 2000). Extending the current work on Hmong American undergraduates (Lin et al., 2015), the study provided an indepth exploration of the differences in and relationships of the psychosociocultural educational experiences of Hmong American undergraduates and their academic persistence decisions. Given the differences in gender roles and expectations for Hmong American males and females (Chiang et al., 2015; Lee, 1997; Moua, 2003; Vue, 2000; Yang, 2014), the study's first question address differences by gender. Similarly, differences by class standing (lower-division and upper-division) were explored as increased time within the environmental context influences their perceptions (Bennett \& Okinaka, 1990; Lin et al., 2015; Lor, 2008; Vue, 2013). Given the paucity of literature on Hmong American undergraduates, no specific hypotheses were posed by gender or class standing for each of the study's variables (Question 1). In addition, it was anticipated that differences in strengths of relationships would similarly emerge by gender and class standing (Question 2). Using an integrative approach, it was hypothesized that the psychological, social, and cultural dimensions would each uniquely and collectively influence students' educational 
experiences and predict academic persistence decisions (Question 3). Yet, given the extant research with Hmong American undergraduates (Lee, 1997; Lin et al., 2015; Lor, 2008; Xiong \& Lam, 2013), it was anticipated that each dimension would explain a portion of the variance of persistence decisions, with the psychological dimension accounting for the largest portion of the collective variance.

\section{Method}

\section{Study Setting and Procedure}

Students were recruited from a large, predominantly White public university in the Midwest. Due to the low number of Hmong American students on campus (approximately 300 students at the time of the study), recruitment efforts focused on Hmong student organizations, Hmong language and culture courses, and a federally-funded student service program. Also, the researchers asked participants if they knew of other students who might be interested in participating in the study to reach as many Hmong American students as possible.

Student organization leaders, instructors, and program directors were asked to forward recruitment materials to their students, which informed them of the study (a 45-minute survey about their educational experiences) and days and times that the researcher(s) would be at their respective sites to administer the survey. The surveys were completed in-group settings (e.g., class, student organization event) and returned at the time of distribution. Students who began the survey at the group time but had to leave (e.g., class) were provided a postage-paid return-addressed envelope to return their completed survey. It is estimated that five completed surveys were returned in this manner. Study recruitment occurred in the spring and early summer semester of a single academic year. Snacks and soda were offered to students during the time that they completed the survey. A total of 149 surveys were distributed with 107 returned completed for a response rate of $71.8 \%$.

\section{Study Participants}

Of the students who completed the survey, four were graduate students and not included in the study's analyses. The 103 Hmong American undergraduates (53 females and 50 males), ranged in age from 17 to $31(M=20.58, S D=2.05)$, with the majority between 18 and $22(87.3 \%)$ years of age. There were 29 first-years (28.4\%), 18 sophomores (17.6\%), 20 juniors (19.6\%), 23 seniors $(22.5 \%)$ and 12 fifth-year seniors $(11.8 \%)$, and one person did not respond, with self-reported grade point averages ranging from 2.00 to $3.70(M=2.93, S D=.38)$. Most of the students were members of a Hmong-specific student organization (68\%) who reported having mostly Hmong friends at school (62\%). Also, most of the students indicated receiving financial aid (94\%), while half $(52 \%)$ also participated in the work-study program. Most (92\%) students were U.S.-born who spoke Hmong at home (91\%). More than half of the participants' mothers $(56.3 \%)$ were reported as having no formal education as compared to one-third $(33.3 \%)$ of the fathers. The majority of students had a brother (78\%) or a sister (90\%) who had completed a college degree. 


\section{Instrumentation}

The survey packet consisted of a consent letter, demographic form (e.g., age, generational status) and 11 counterbalanced measures (10 standardized, 1 researcher-developed) assessing the dimensions of the PSC model and academic nonpersistence decisions. Given the large number of scales used, only brief descriptions are provided. Further, previous use of the scale was not included; however, each had adequate internal consistency with Asian American or Hmong American undergraduates in previous studies (e.g., Gloria \& Ho 2001; Lin et al., 2015).

\section{Psychological Dimension}

Self-efficacy. Students' confidence to complete specific college-related tasks (10 items) was assessed using the College Self-Efficacy Inventory (Solberg, O’Brien, Villareal, Kenner, \& Davis, 1993). Higher scores indicated a greater level of confidence in their ability to complete specific college-related tasks (e.g. write course papers).

Phoniness. A 14-item scale, the Imposter Syndrome Scale (Harvey, 1982) measured the degree to which imposter feelings exist within an individual. Higher scores indicated increased feelings of phoniness such as "I often feel I am concealing secrets about myself from others."

Self-esteem. The Self-Esteem Scale (Rosenberg, 1965) (10 items) assessed feelings of acceptance and self-worth. Higher scores indicated higher perceptions of self-esteem. A sample item is "On the whole, I am satisfied with myself."

\section{Social Dimension}

Support. The Perceived Social Support Inventory (Procidano \& Heller, 1983) consisting of two subscales, measured perceptions of support, information, and feedback received from friends and family, respectively. Each subscale contains 20 parallel statements emphasizing either family or friends (i.e., My family/friends enjoys hearing about what I think). Higher scores indicated greater perceived social support provided by family or friends.

Encouragement. The Parental Educational Encouragement Scale (Gloria, Robinson Kurpius, Wilson, \& Hamilton, 1999) assessed parental support and encouragement regarding education (14 items). Higher scores indicated increased levels of perceived parental support.

Expectations. The Perceived Familial/Communal Educational Expectations Scale (Researcher-developed) was researcher-developed based on the importance and role of Hmong family educational expectations (DePouw, 2003; Lee, 2007) to assess students' perceived educational expectations from their family and community (15 items). Higher scores indicated greater perceived educational expectations. 


\section{Cultural Dimension}

Ethnic identity. The Multigroup Ethnic Identity Measure (Phinney, 1992) assessed meaning and importance of ethnic identity common to different ethnic groups (14 items). Higher scores representing a more positive ethnic identity. A sample item includes: "I feel good about my cultural or ethnic background."

Congruity. Originally-developed for and validated with Chicano/a students, the Cultural Congruity Scale (Gloria \& Robinson Kurpius, 1996) measured fit of one's personal values and those of the university environment (13 items). Higher scores indicated a greater fit of values. A sample item includes: "As an ethnic minority, I feel as if I belong on this campus."

Environment. Also developed for and validated with Chicano/a students, the University Environment Scale (Gloria \& Robinson Kurpius, 1996) assessed students' perception of the university environment (14 items). Higher scores reflect more positive perceptions of the university environment (e.g., "Faculty have been available to help me make course choices").

Acculturation. The Asian American Multidimensional Acculturation Scale (Chung, Kim, \& Abreu, 2004) (3 scales with 15 items each) examined Asian Americans socialization and engagement in behavioral norms of 1) one's own Asian culture, 2) other Asian American culture, and 3) European American culture. Higher scores indicated greater acculturation to the respective cultural group. Participants responded based on how much they identified with behaviors of each cultural group.

Persistence. The Persistence/Voluntary Dropout Decisions Scale (Pascarella \& Terenzini, 1980) measured student's educational experiences and subsequent academic nonpersistence decisions (30 items). Items reflected concepts of intellectual development, peer-group interactions, interactions with faculty, and institutional and goal commitments (e.g., "It is important for me to graduate from college"). For this study, a higher score reflected increased persistence decisions.

\section{Results}

Each of the study's variables yielded internal consistencies that ranged from .70 to .95 and are presented in Table 1 along with scale descriptives. Missing data for the study's scales was managed using an $80 \%$ mean scale score.

\section{Mean Group Differences}

To determine group differences by gender and class standing (Question 1), a series of $t$-tests were conducted. Differences emerged for perceived family support and cultural congruity for both gender and class standing where females reported higher means $(M=4.01, S D=.75 ; M=5.06$, $S D=.98)$ than did males $(M=3.60, S D=.72 ; M=4.55, S D=.89)$ and lower-division students $(M=3.97, S D=.69 ; M=5.04, S D=.91)$ were higher than upper-division students $(M=3.66, S D$ $=.78 ; M=4.64, S D=.99)$, respectively. Females also reported higher perceived friend support $(M$ 
$=3.81, S D=.61)$ than did males $(M=3.58, S D=.52)$. Finally, lower-division students reported lower self-esteem $(M=3.11, S D=.60)$ than did upper-division students $(M=3.38, S D=.45)$.

Table 1

Means, Standard Deviations, Internal Consistencies, and Correlations of the Study's Variables

\begin{tabular}{|c|c|c|c|c|c|c|c|c|c|c|c|c|c|c|c|c|}
\hline \multirow[b]{2}{*}{ Variables } & \multirow[b]{2}{*}{$M$} & \multirow[b]{2}{*}{$S D$} & \multirow[b]{2}{*}{$\alpha$} & \multirow[b]{2}{*}{2} & \multirow[b]{2}{*}{3} & \multirow[b]{2}{*}{4} & \multirow[b]{2}{*}{5} & \multirow[b]{2}{*}{6} & \multicolumn{2}{|c|}{ Correlations } & \multirow[b]{2}{*}{9} & \multirow[b]{2}{*}{10} & \multirow[b]{2}{*}{11} & \multirow[b]{2}{*}{12} & \multirow[b]{2}{*}{13} & \multirow[b]{2}{*}{14} \\
\hline & & & & & & & & & 7 & 8 & & & & & & \\
\hline 1. Self-esteem & 3.24 & .55 & .89 & $.47^{* * *}$ & $.58^{* * *}$ & $.33^{* * *}$ & $.29^{* *}$ & .03 & .01 & $.37^{* * *}$ & $.24^{*}$ & $.20^{*}$ & .09 & .19 & -.02 & $.23^{*}$ \\
\hline 2.Self-efficacy & 4.94 & 1.05 & .92 & & $.65^{* * *}$ & $.43^{* * *}$ & $.26^{* *}$ & .04 & .10 & $.32^{* * *}$ & $.27^{* *}$ & $.25^{*}$ & $.26^{* *}$ & .16 & -.03 & $.40^{* * *}$ \\
\hline $\begin{array}{l}\text { 3.Phoniness } \\
\text { 4.Friend }\end{array}$ & 3.30 & .85 & .82 & & & $.52^{* * * *}$ & $.45^{* * *}$ & -.10 & -.15 & $.33^{* * *}$ & $.32^{* * *}$ & $-.30^{* *}$ & $.32^{* * *}$ & $.38^{* * *}$ & .04 & $.47^{* * *}$ \\
\hline $\begin{array}{l}\text { Support } \\
\text { 5.Family }\end{array}$ & 3.70 & .58 & .89 & & & & $.40^{* * *}$ & .06 & .09 & $.39^{* * *}$ & $.20^{*}$ & $.23^{*}$ & $.21^{*}$ & $.35^{* * *}$ & .10 & $.50^{* * *}$ \\
\hline $\begin{array}{l}\text { Support } \\
6 .\end{array}$ & 3.81 & .76 & .95 & & & & & .10 & .05 & $.27^{* *}$ & .19 & $.21^{*}$ & $.33^{* * *}$ & $.51^{* * *}$ & .03 & $.36^{* * *}$ \\
\hline Encouragement & 3.75 & 1.03 & .90 & & & & & & .08 & .13 & .19 & .15 & $-.21^{*}$ & -.02 & -.03 & -.07 \\
\hline $\begin{array}{l}\text { 7. Expectations } \\
\text { 8.Ethnic }\end{array}$ & 3.85 & 0.74 & .91 & & & & & & & $.35^{* * *}$ & $.27^{* *}$ & $.28^{* *}$ & .12 & -.18 & -.04 & .18 \\
\hline $\begin{array}{l}\text { Identity } \\
\text { 9. Acculturation }\end{array}$ & 3.26 & .49 & .70 & & & & & & & & $.70^{* * *}$ & $.52^{* * * *}$ & $.20^{*}$ & .07 & -.11 & $.20^{*}$ \\
\hline $\begin{array}{l}\text { Own } \\
10 . \\
\text { Acculturation }\end{array}$ & 4.39 & .80 & .89 & & & & & & & & & $.74^{* * *}$ & $.20^{*}$ & .06 & -.05 & .07 \\
\hline $\begin{array}{l}\text { Other } \\
11 . \\
\text { Acculturation }\end{array}$ & 4.28 & .88 & .92 & & & & & & & & & & $.31^{* *}$ & .13 & .06 & .11 \\
\hline White & 3.99 & .95 & .92 & & & & & & & & & & & .19 & -.09 & $.24^{*}$ \\
\hline $\begin{array}{l}\text { 12. Congruity } \\
13 .\end{array}$ & 4.81 & .97 & .82 & & & & & & & & & & & & $.39^{* * *}$ & $.25^{* *}$ \\
\hline Environment & 4.85 & .75 & .79 & & & & & & & & & & & & & $.24^{*}$ \\
\hline 14. Persistence & 3.56 & .34 & .73 & & & & & & & & & & & & & - - \\
\hline
\end{tabular}

Notes. ${ }^{*} p \leq .05,{ }^{* *} p \leq .01,{ }^{* * *} p \leq .001$

\section{Differences of Coefficients}

To determine whether the strength of the correlations were significantly different by gender and class standing (Question 2), Fisher's $r$ to $z$ transformations were performed. Results revealed stronger associations between self-esteem and persistence decisions for males $(r=.42)$ as compared to females $(r=.03)(z=2.03, p \leq .05)$. Males $(r=.32)$ also had a stronger relationship between other Asian American acculturation and persistence decisions than females $(r=-.15)(z$ $=2.32, p \leq .05)$. Follow-up analysis was conducted revealing stronger associations between selfesteem and intellectual phoniness for males $(r=.74)$ than females $(r=.48)(z=2.10, p \leq .05)$. Differences in strengths of relationships by class standing were not revealed.

\section{Hierarchical Regression}

To assess the increases in explained variance and changes in regression coefficients for each dimension independently and collectively without presumed priority, the different variable sets (i.e., psychological, social, cultural) were entered into a four-step hierarchical regression (Cohen, Cohen, Aiken, \& West, 2003) consistent with the extant literature (Question 3, See Table 2). 
Controlling for gender and class standing in Step 1, a non-significant amount of variance was yielded. In Step 2 (psychological dimension), 21\% of the variance was accounted, where intellectual phoniness emerged as the only significant negative predictor. In Step 3 (social dimension), $12 \%$ of the variance was explained, with friend support as the only positive predictor. Finally, in Step 4 (cultural dimension) $8 \%$ of the variance was accounted, with the perception of the university environment the only significant positive predictor. Because several of the independent variables were moderately correlated, a variance inflation factor was conducted yielding scores (1.00 to 3.93) well-below the standard cut-off of 10, indicating low concern for multicollinearity (Cohen et al., 2003).

Table 2

Summary of Hierarchical Regression for PSC Variables predicting Academic Persistence Decisions (N=99)

\begin{tabular}{|c|c|c|c|c|c|c|}
\hline \multicolumn{2}{|c|}{ Variables } & \multirow[t]{2}{*}{$\beta$} & \multirow[t]{2}{*}{$t$} & \multirow[t]{2}{*}{$R^{2}$} & \multirow[t]{2}{*}{$\Delta R^{2}$} & \multirow[t]{2}{*}{$\Delta F$} \\
\hline Step 1 & & & & & & \\
\hline & Controlled variables & & & .02 & .02 & 1.03 \\
\hline & Gender & .14 & 1.42 & & & \\
\hline & Class standing & .027 & .27 & & & \\
\hline \multicolumn{7}{|l|}{ Step 2} \\
\hline & Psychological & & & .23 & .21 & $8.45^{\mathrm{a}}$ \\
\hline & Self-esteem & -.08 & -.67 & & & \\
\hline & Self-efficacy & .19 & 1.53 & & & \\
\hline & Phoniness & $-.37^{*}$ & -2.80 & & & \\
\hline \multicolumn{7}{|l|}{ Step 3} \\
\hline & Social & & & .35 & .12 & $4.15^{\mathrm{b}}$ \\
\hline & Friend Support & $.32^{*}$ & 3.05 & & & \\
\hline & Family Support & .14 & 1.31 & & & \\
\hline & Encouragement & -.13 & -1.50 & & & \\
\hline \multirow{7}{*}{ Step 4} & Expectations & .10 & 1.11 & & & \\
\hline & & & & .43 & .08 & $3.11^{\mathrm{c}}$ \\
\hline & Cultural & & & & & \\
\hline & Ethnic identity & .07 & .46 & & & \\
\hline & Acculturation Own & -.17 & -1.30 & & & \\
\hline & Congruity & -.12 & -1.06 & & & \\
\hline & Environment & $-.30^{*}$ & 3.16 & & & \\
\hline
\end{tabular}

\section{Discussion}

There is a paucity of research on the Hmong American undergraduates' educational experiences, with most of the extant literature qualitative in nature (e.g., Lor, 2008; Xiong \& Lam, 2012; Vue, 2013). Although this growing literature provides insight into and understanding of Hmong American students' educational experiences, interpretation of this study's results was conducted cautiously to avoid assuming that all Hmong hold the same values or behaviors, particularly as behavioral acculturation occurs faster than values acculturation (Kim \& Abreu, 2001). As a result, multiple perceptions or experiences based on psychological, social, cultural, political, and economic aspects are integrated into understanding Hmong American undergraduates' educational 
experiences. The following discussion uses a "psychosociocultural framework" (Gloria \& Rodriguez, 2000) to provide an explanation of the study's findings within the extant literature.

Examining 103 Hmong American undergraduates' psychological, social, and cultural dimensions uniquely and collectively explained a proportion of their academic persistence decisions. Primarily second-generation within the U.S., first-generation to college, the students were of traditional college age (18 to 22). Most of the students reported being from large families (1 to 8 brothers, 1 to 9 sisters), whose parents had low educational attainment in comparison to other Asian American adults (U.S. Census, 2013). The majority of students were affiliated with an ethnic-specific student organization, more than half were members of a federally-funded support program for first-generation college students, and almost all received some financial aid.

\section{Predicting Academic Persistence Decisions}

That the psychosociocultural approach posits that each of the dimensions is interdependent and necessarily integrated to better understand students' persistence processes (Gloria \& Rodriguez, 2000), the study's findings are similarly discussed in combination. First, within the psychological dimension, intellectual phoniness was the only significant negative predictor. As first-generation college students, Hmong American undergraduates are often held accountable to familial and communal expectations to succeed (Lee, 2007), they are charged with the responsibility for the family. As a result, students may experience pressure, question their abilities to meet such expectations (Hutchinson, 1997), and experience a sense of phoniness. Simultaneously, Hmong American undergraduates are often marginalized and likely to experience microaggressions within the university environment (Cokley et al., 2012; Lin et al., 2015) and also question their abilities to succeed, adding to their sense of phoniness. If Hmong American undergraduates are unable to approach their families due to pressures about their academic expectations (Lee, 1997) they may turn to their peers for support (Swartz, et. al., 2003), a finding evidenced by the role of perceived social support (the only significant predictor within the social dimension) in this study. Peer support allows students to feel connected and develop necessary relationships (Delgado-Romero \& Hernandez, 2002), provide a sense of increased college adjustment (Chong, et. al., 2006), salience of ethnic identity (Vue, 2013), and decreased sense of intellectual phoniness and nonacademic persistence decisions (Lin et al., 2015). Finally, as evidenced in studies of Asian and Hmong American undergraduates (e.g., Gloria \& Ho, 2003; Lin et al., 2015) this study similarly found that students who perceived a more positive university environment were more likely to make decisions to stay in school.

In combination, the three dimensions (i.e., psychological, social, and cultural) lend a holistic context for understanding students' processes with the psychological dimension uniquely accounting for the largest portion of the collective variance followed by the social and cultural dimensions. It was the specific variables of intellectual phoniness, perceived friend support, and perceptions of the university environment that were key in explaining the Hmong American undergraduates' academic persistence decisions. Together the findings provide a platform to understand the gender and class standing differences. 


\section{Gender Differences}

As anticipated, gender differences emerged such that males had a stronger relationship of other Asian American acculturation and self-esteem to persistence decisions, respectively than did females. Having a connection to other Asians on campus may assist males' notion that they have a larger group of racially-similar students with whom to connect is more relevant to persistence as compared their female counterpart (Thao et al., 2009). Likewise, having a sense of esteem as Hmong male students on campus, particularly within the changing gender role for Hmong males was salient to their persistence decisions (Her \& Gloria, 2016). These findings move the Hmong undergraduate literature in a new direction as gender differences have not been previously yielded (Lin et al., 2015) nor been a specific focus of study (e.g., Lee, 1997; Ngo, 2002). As the cultural literature on U.S. Hmong populations address gender role traditions for males and females (Faderman \& Xiong, 1998; Her \& Gloria, 2016; Moua, 2003; Yang, 2014), how Hmong cultural values and expectations by gender are translated within the university's context is a warranted exploration.

Because Hmong males are numerically-underrepresented and perceived stereotypically on the campus of study, they may self-protect and negotiate their educational settings (e.g., residence halls, classrooms) by engaging in behaviors reflective of Pan-Asian values rather than specific Hmong cultural values. In doing so, they may gain a greater connection to a more visible and dominant group of students (i.e., Asian Americans), particularly as this study's Hmong American males represented less than half of one percent of the campus population. Further, their self-esteem was more strongly related to their feelings of phoniness, which may in part explain the importance of self-esteem in relation to persistence decisions. That is, on a predominantly White university campus, with incidents of overt micro-aggressions against the Hmong American student population, the internalization of these experiences (i.e. feelings of unworthiness on campus) may have perpetuated an increased sense of phoniness.

Considering that within many Hmong families traditional gender scripts remain prevalent, males are given higher status and greater privileges compared to their female counterparts (e.g., fewer personal and social restrictions) (Faderman \& Xiong, 1998; Moua, 2003). To the degree that traditional gender roles are salient, wherein males are central to the family and the family's wellbeing, the study's males may have experienced status displacement on campus, a process evidenced for Hmong males with the shift of gender roles (Yang, 1997). The change of gender roles may in part lend support for their lower sense of cultural congruity (e.g., having a cultural status in an environment that does not value them) and their self-esteem and Pan-Asian acculturation being more strongly related to their academic persistence decisions than females. As this study is among the first to reveal gender differences for Hmong American undergraduates, it is clear that research that examines familial and cultural influences by gender is needed.

Traditionally, Hmong females are instrumental to the creation and on-going maintenance (e.g., daily home functioning, emotional support) of the family structure (Faderman \& Xiong, 1998; Moua, 2003). Vue (2000) speculated that Hmong females maintain their Hmong and American cultural identity due to their multiple roles in and outside of the home, within the context of Asian American females acculturating quicker than their male counterparts (Sue, 1998). Traditional Hmong families generally enculturate conservative expression of emotion with females frequently serving as the emotional providers (Lee, n.d). Given the different cultural roles between males and females, it is plausible that the study's females would hold higher perceptions of social support from family and friends. Attuned to the expression of support, in particular in the 
family (Park, Vo, \& Tsong, 2009), Hmong undergraduate females have placed greater importance on support through peer relationships (Lin et al., 2015).

\section{Class Differences}

Finally, group mean differences by class standing were also revealed. As racial and ethnic minority students progress across their academic tenure they may become more aware of how they are valued on campus and attuned to discriminatory and inequitable events (Cokley et al., 2012; Gloria, Castellanos, Segura-Herrera, \& Mayorga, 2010). As a result of the accumulated negative experiences or micro-aggressions (Ong et al., 2013), the upper-division students' sense of cultural congruity may have decreased in comparison to lower-division students (who may not yet be attuned to negative experiences), a finding similar to Lin et al.'s (2015) study of 85 Hmong American undergraduates. Along with students' decreased sense of cultural congruity and negotiation of negative educational experiences, students' self-esteem diminishes. That is, a student who is exposed to a hostile or negative learning environment may over time question their competence or intelligence, likely, negatively influencing their sense of self as a Hmong student on campus (Lin et al., 2015).

\section{Limitations of the Study}

Several limitations warrant review. First, the measurement of acculturation emphasized behaviors rather than values. Values measurement lends insight into the perceptions of how affiliated one feels to his/her cultural group, whereas behaviors reveal how frequently one may engage in particular cultural group behaviors (Kim \& Abreu, 2001). Similarly, the acculturation scale assessed language competence and cultural knowledge which may have overestimated the participants' adherence to White European culture. That Hmong written language did not occur until the 1960's, many individuals are unable to read or write Hmong (Faderman \& Xiong, 1998). As such, a cultural values measure specifically for Hmong Americans is needed.

Given the small Hmong American student population on the large predominantly White campus, the study's recruitment focused on Hmong student-focused organizations and a specific student services program and thus introduced sample bias. The students involvement with student organizations may have informed their sense of belonging and like culture friends and support systems (Vue, 2013), a process that most likely positively influence their sense of self or feelings of phoniness. In addition, most of the students received financial aid. As finances influence Hmong undergraduates' educational experiences (Xiong, 2012; Xiong \& Lam, 2013), it is unclear as to how this element may have informed their sense of phoniness or persistence decisions. Despite the sample being more than one-third (36\%) of the campus' Hmong student population, it did not represent all Hmong American students (e.g., non-traditional or commuter students) across class standing equally, and a clear area of future study to understand how Hmong American students negotiate the environment and navigate the needed educational support and financial resources for their educational persistence.

At the time of the study, there were also two significant Hmong racially-based events (one on campus and one in the local community) that undoubtedly influenced the students' sense of belonging and perceived value on campus. It is unclear the extent to which the events affected the 
study's findings; however, the Hmong American students may have responded with greater feelings of phoniness or decreased feelings of belongingness which indirectly influenced by their perception of the university as uncaring and unwelcoming of Hmong students.

\section{Future Research}

The study's findings direct multiple areas of research for Hmong American undergraduates. First, research on cultural and gender role scripts within higher education is needed. Research could explore how males' internalization and socialization of the different cultural and gender role scripts at home influence their experiences on campus and subsequent academic persistence decisions. Next, as student organizations are critical for racial and ethnic minority students to create a sense of family and provide socio-emotional support (Delgado-Romero \& Hernandez, 2002) and bolster a sense of ethnic identity (Vue, 2013), exploring how student organizations provide a sense of belonging and mattering as well as academic support and in turn influences academic persistence decisions is needed. Specifically, determining how student organizations serve as a cultural stabilizer for Hmong males and the degree to which gender role scripts emerge within the structure of the student organizations warrant exploration. Finally, how Hmong males and females undergraduates' use peer support to increase their sense of belonging and its relationship to phoniness could elucidate gender and cultural specific issues. For each of these above-mentioned studies, it is recommended that in-depth interviews and focus groups are conducted to gain more complex and detailed narratives of Hmong American students' educational experiences and persistence processes.

\section{Implications and Recommendations}

As the Hmong American student population grows, it becomes increasingly important to provide environments within higher education that are culturally congruent and welcoming (Museus, 2014; Vue, 2013). The study's findings support the recommendation that university personnel take an active role in recruiting and retaining both Hmong students, staff, and faculty in a diversity of majors (e.g., health sciences, education), as well as increasing representation of the Hmong community in advising and faculty interactions, general curriculum and ethnic-specific courses, residence halls, and university programming (e.g., student and parent/family orientation days, community outreach; Vue, 2013). Assisting students to find campus resources and academic advising and mentoring that are congruent with their cultural and academic needs can ease the process of college life and underscore their sense of efficacy and belonging on campus. Such support can allow Hmong American students to know that all university personnel understand their specific concerns and needs, value them and their contributions to different campus learning communities, and want them to succeed.

In retaining Hmong American undergraduates, the findings reflected the importance of peer support in mitigating possible negative interactions within the university environment that may increase feelings of phoniness or influence academic persistence decisions (Lin et al., 2015). As such, the redirection/re-allocation of university resources to establish and fund peer support groups whose intention is to support minority students academically, such as ethnic-specific student-initiated and student-run retention programs is warranted. It is further recommended that 
Hmong-specific spaces (e.g., residence halls in Vue, 2013) are established to create a culturally relevant and integrative campus community where Hmong American students can readily identify individuals, networks, and resources for psychological, social, cultural, and academic support. Doing so, may allow Hmong American undergraduates to feel a greater sense of belonging and cultural congruity, decreasing their sense of phoniness, and ultimately increasing their belief that they can academically persist.

\section{Author's Notes}

"Txoj kev ntshiab" in the Hmong language means "the new road" or the "clear road" referring to the new "life" and educational opportunities in the U.S. available to Hmong immigrants. The authors acknowledge the contributions of Asia Thao and Sheeyee Chang. Correspondence concerning this article should be addressed to Pa Her, Department of Counseling Psychology, University of Wisconsin-Madison, 335 Education Building - 1000 Bascom Mall, Madison, WI 53706-1398 (email: her1@wisc.edu).

\section{References}

Bennett, C., \& Okinaka, A. M. (1990). Factors related to persistence among Asian, Black Hispanic, and White undergraduates at a predominantly white university: Comparison between first and fourth year cohorts. The Urban Review, 22, 33-60. doi: 10.1007/bf01110631

Bosher, S. (1997). Language and cultural identity: A study of Hmong students at the postsecondary level. TESOL Quarterly, 31(3), 593-603. doi: 10.2307/3587843

Castellanos, J. C., \& Gloria, A. M. (2007). Research considerations and theoretical applications for best practices in higher education: Latina/os achieving success. Journal of Hispanic Higher Education, 6(4), 378-396. doi: 10.1177/1538192707305347

Chong, W., Huan, V., Yeo, L., \& Ang, R. (2006). Asian adolescents' perceptions of parent, peer, and school support and psychological adjustment: The mediating role of dispositional optimism. Current Psychology, 25(3), 212-228. doi: 10.1007/s12144-006-1004-6

Clance, P. R., \& Imes, S. A. (1978). The imposter phenomenon in high achieving women: Dynamics and therapeutic intervention. Psychotherapy: Theory, Research \& Practice, 15, 241-247. doi: 10.1037/h0086006

Chiang, A., Fisher, J., Collins, W., \& Ting, M. (2015). (Mis)labeled: The challenge of academic capital formation for Hmong American high school students in an urban setting. Journal of Southeast Asian American Education and Advancement, 10, 1-32. doi:10.7771/21538999.1118

Chung, R. H. G., Kim, B. S. K., \& Abreu, J. M. (2004). Asian American Multidimensional Acculturation Scale: Development, factor analysis, reliability and validity. Cultural Diversity and Ethnic Minority Psychology, 10, 66-80. doi: 10.1037/1099-9809.10.1.66

Cokley, K., McLain, S., Enciso, A., \& Martinez, M. (2012). An examination of the impact of minority stress and impostor feelings on the mental health of diverse ethnic minority college students. Journal of Multicultural Counseling and Development, 41, 82-95. doi: 10.1002/j.2161-1912.2013.00029.x 
Cohen, J., Cohen, P., West, S., \& Aiken, L. (2003). Applied multiple regression/correlation analysis for the behavioral sciences (3rd ed.). Hillsdale, NJ: Lawrence Erlbaum. ISBN: 9780805822236

Delgado-Romero, E., \& Hernandez, C. (2002). Empowering Hispanic students through student organizations: Competencies for faculty advisors. Journal of Hispanic Higher Education, 1, 144-157. doi: 10.1177/1538192702001002004

DePouw, C. (2003). Familiar foreign: Hmong American students engaging and resisting in America. Paper presented at the Annual Meeting of the American Educational Research Association, Chicago. IL.

Faderman, L., \& Xiong, G. (1998). I begin my life all over: The Hmong and the American immigrant experience. Boston, MA: Beacon Press.

Gloria, A. M., \& Castellanos, J. (2003). Latino/a and African American students at predominantly White institutions: A psychosociocultural perspectives of educational interactions and academic persistence. In J. Castellanos \& L. Jones (Eds.), The majority in the minority: Retaining Latinalo faculty, administrators, and students (pp. 71-92). Sterling, VA: Stylus.

Gloria, A. M., Castellanos, J., Segura-Herrera, T. A., \& Mayorga, M. (2010). Understanding acculturation, cultural congruity, and attitudes toward counseling of Latina college students. Journal of College Counseling, 13, 126-140. doi: 10.1002/j.21611882.2010.tb00054.x

Gloria, A. M., \& Ho, T. A. (2003). Environmental, social, and psychological experience of Asian American undergraduates: Examining issues of academic persistence. Journal of Counseling and Development, 81, 93-105. doi: 10.1002/j.1556-6678.2003.tb00230.x

Gloria, A. M., \& Pope-Davis, D. (1997). Cultural ambience: The importance of a culturally aware learning environment in the training and education of counselors. In D. B. Pope-Davis \& H. L. K. Coleman (Eds.), Multicultural counseling competencies: Assessment, education and training, and supervision (pp. 242-259). Thousand Oaks, CA, US: Sage Publications. doi: 10.4135/9781452232072.n11

Gloria, A. M., \& Robinson Kurpius, S. E. (1996). The validation of the cultural congruity scale and the university environment scale with Chicano/a students. Hispanic Journal of Behavioral Sciences, 18, 533-549. doi: 10.1177/07399863960184007

Gloria, A. M., Robinson Kurpius, S. E., Hamilton, K. D., \& Willson, M. S. (1999). African American academic nonpersistence at a predominantly White institution: Issues of social support, university comfort, and self-beliefs. Journal of College Student Development, 40, 257-268.

Gloria, A. M., \& Rodriguez, E. R. (2000). Counseling Latino university students: Psychosociocultural issues for consideration. Journal of Counseling and Development, 78, 145-154. doi: 10.1002/j.1556-6676.2000.tb02572.x

Gloria, A. M., \& Segura-Herrera, T. A. (2004). Ambrocia and Omar go to college: A psychosociocultural examination of Chicana/os in higher education. In R. J. Velasquez, L. M. Arellano, \& B. W. McNeill (Eds.), The handbook of Chicana/o psychology and mental health (pp. 401-425). Mahwah, NJ: Lawrence Erlbaum Associates.

Harvey, J. C. (1982). The imposter phenomenon and achievement: A failure to internalize success (Doctoral dissertation, Temple University, 1981). Dissertation Abstracts International, 42, 4969B-4970B. 
Her, P., \& Gloria, A. M. (2016). Kev txhawb siab: Hmong parents' educational encouragement of their undergraduate daughter/son. Journal of Family Diversity in Education, 2(2), 1934.

Hutchinson, R. (1997). The educational performance of Hmong students in Wisconsin. Milwaukee, WI: Wisconsin Policy Research Institute.

Kim, B. S. K., \& Abreau, J. M. (2001). Acculturation measurement: Theory, current instruments, and future directions. In J. G. Ponterotto, J. M. Casas, L. A. Suzuki, \& C. M. Alexander (Eds.). Handbook of multicultural counseling (2nd ed.), pp. 394-424. Thousand Oaks, CA: Sage.

Lee, G. Y. (n.d.) Hmong worldview and social structure, Lao Study Review. Retrieved on from http://home.vicnet.net.au/ lao/laostudy/hmrelate.htm.

Lee, S. C. (2007). The self-rated social well-being of Hmong college students in Northern California, Hmong Studies Journal, 8, 1-19. http://hmongstudies.org/SLeeHSJ8.pdf

Lee, S. J. (1997). The road to college: Hmong American women's pursuit of higher education. Harvard Educational Review, 67, 803-827. Retrieved from http://her.hepg.org/content/0296u12hu7r65562/fulltext.pdf

Lor, P. (2008). Key life experiences contributing to Hmong students' matriculation. Multicultural Education, 16(1), 39-47. http://files.eric.ed.gov/fulltext/EJ822397.pdf

Lin, M. M., Her, P., \& Gloria, A. M. (2015). Kawm ntawv qib siab: Understanding the psychosociocultural educational experiences of Hmong American undergraduates. Journal of Southeast Asian American Education and Advancement, 10(1), Article 7. doi:10.771/2153-8999.1123

Moua, T. (2003). The Hmong culture: Kinship, marriage, \& family systems (Unpublished Master's thesis). Menomonie, WI: University of Wisconsin-Stout.

Museus, S. D. (2014). The Culturally Engaging Campus Environments (CECE) Model: A new theory of success among racially diverse college students populations. In M. B. Paulsen (Ed.), Higher education: Handbook of theory and research (Vol.29, pp. 189-227). New York, NY: Springer Science.

Ngo, B. (2013). Culture consciousness among Hmong immigrant leaders: Beyond the dichotomy of cultural essentialism and cultural hybridity, American Educational Research Journal, 50(5), 958-990. doi: 10.3102/0002831213494262

Ngo, B. (2002). Contesting "culture": The perspectives of Hmong American female students on early marriage. Anthropology \& Education Quarterly, 33, 163-188. doi: 10.1525/aeq.2002.33.2.163

Ong, A. D., Burrow, A. L., Fuller-Rowell, T. E., Ja, N. M., \& Sue, D. W. (2013). Racial microaggressions and daily well-being among Asian Americans. Journal of Counseling Psychology, 60(2), 188-199.

Osajima, K. (1991). Breaking the silence: Race and the educational experiences of Asian American students. In M. Foster (Ed.), Readings on equal education, (pp. 115-134). New York, NY: AMS Press.

Osajima, K. (1995). Racial politics and the invisibility of Asian Americans in higher education. Educational Foundations, 9, 35-53.

Park, Y. S., Vo, L., \& Tsong, Y. (2009). Family affection as a protective factor against the negative effects of perceived Asian values gap on the parent-child relationship for Asian American male and female students. Cultural Diversity and Ethnic Minority Psychology, 15(1), 1826. doi: $10.1037 / \mathrm{a} 0013378$ 
Pascarella, E. T., \& Terenzini, P. T. (1980). Predicting freshman persistence and voluntary dropout decisions from a theoretical model. Journal of Higher Education, 51, 60-75.

Phinney, J. S. (1992). The multigroup ethnic identity measure: A new scale for use with diverse groups. Journal of Adolescent Research, 7(2), 156-176. doi: 10.2307/1981125

Procidano, M. E., \& Heller, K. (1983). Measures of perceived social support from friends and from family: Three validation studies. American Journal of Community Psychology, 11, 1-24. doi: 10.1007/BF00898416

Rosenberg, M. (1965). Society and the adolescent self-image. Princeton, NJ: Princeton University Press.

Solberg, V. S., O’Brien, K., Villareal, P., Kennel, R., \& Davis, B. (1993). Self-efficacy and Hispanic college students: Validation of the college self-efficacy inventory. Hispanic Journal of the Behavioral Sciences, 15, 80-95. doi: 10.1177/07399863930151004

Sue, D. W. (1998). The interplay of sociocultural facets on the psychological development of Asians in America: Counseling American minorities ( ${ }^{\text {th }}$ ed.) (pp. 205-213). New York, NY: McGraw-Hill.

Suzuki, B. H. (1994). Higher education issues in the Asian American community. In M. J. Justiz, R. Wilson, \& L. G. Bjork (Eds.), Minorities in higher education (pp. 258-285). Phoenix, AZ: Oryx Press.

Swartz, T., Lee, J. C., \& Mortimer, J. T. (2003). Achievements of first-generation Hmong youth: Findings from the youth development survey. CURA Reporter, 33, 15-21. Retrieved from https://datacenter.spps.org/sites/2259653e-ffb3-45ba-8fd6-04a024ecf7a4/uploads/SwartzLee-Mortimer_11-5-2003_4-22-2005.pdf

Thao, B. J., Her, P., Lee, D., Chang, S., Thao, A., Aroonsavath, L., Gloria, A. M., \& Sengkhammee, J. T. (2009). Kawm ntawv qib siab: Experiences of Hmong American undergraduates. Paper presented at the Annual American Psychological Conference, Toronto. Canada.

U.S. Census Bureau. (2013). American community survey: Selected race/ancestry. Retrieved from http://factfinder2.census.gov/faces/tableservices/jsf/pages/ productview.xhtml?pid=ACS_13_1YR_S0201\&prodType=table

Vue, M. (2000). Perception of early marriage and future educational goals attainment for Hmong female adolescents. Unpublished master's theses, Wisconsin, WI: University of Wisconsin Stout.

Vue, R. (2013). Campus contexts and Hmong students' experiences negotiating identity and higher education. In S.D. Museus, D.C. Maramba, \& R.T. Teranishi (Eds.), The misrepresented minority: New insights on Asian Americans and Pacific Islanders, and the implications for higher education (pp.182-197). Sterling, VA: Stylus Publishing.

Xiong, Y. S. (2012). Hmong Americans' educational attainment: Recent changes and remaining challenges. Hmong Studies Journal, 13 (2), 1-8. Retrieved from http://hmongstudies.org/YSXiongHSJ13.2.pdf

Xiong, S., \& Lam, S. K. (2013). Factors affecting the success of Hmong college students in America. British Journal of Guidance \& Counselling, 41(2), 132-144. doi: 10.1080/03069885.2012.713909

Xiong, S., \& Lee, S. E. (2011). Hmong students in higher education and academic support programs. Hmong Studies Journal, 12, 1-20. Retrieved from http://hmongstudies.org/XiongandLeeHSJ12. pdf 
Journal of Southeast Asian American Education and Advancement, Vol. 12 [2017], Iss. 1, Art. 1

Yang, A. (2014). Themes in the career development of 1.5-generation Hmong women. Journal of Career Development, 41(5), 402-425. doi: 0.1177/0894845313507775

Yang, K. (1997). Hmong mens' adaptation to life in the United States. Hmong Studies Journal, $1(2), 1-22$. 


\section{About the Authors}

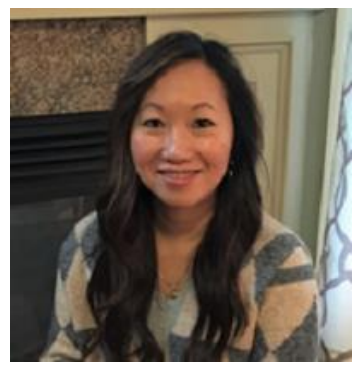

Jenjee T. Sengkhammee is a licensed psychologist in private practice specializing in culturally-oriented care. Her professional interests are in understanding of the complex role of race and culture in cross-cultural therapy relationships.

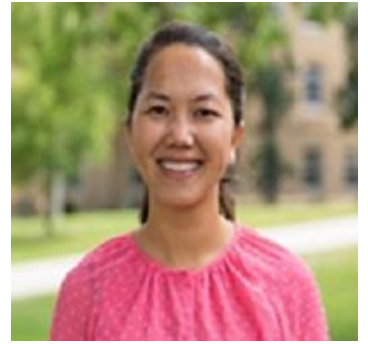

Pa Her is a doctoral student in the Department of Counseling Psychology at the University of Wisconsin-Madison. Her research examines the educational experiences of Hmong American students in higher education and the career development of racial ethnic minority individuals.

Alberta M. Gloria is a Professor in the Department of Counseling Psychology at the University of Wisconsin-Madison. Her research focuses on a Psychosociocultural understanding of the educational processes and coping strategies that facilitate academic persistence and educational wellness for students of color in higher education.

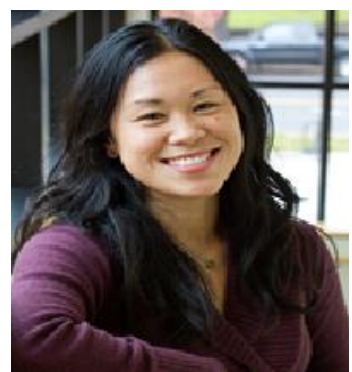

Mariko M. Lin is a senior staff psychologist and the Education and Prevention Outreach Director at the University of Oregon's Counseling \&Testing Center. Her clinical and research interests focus on the persistence and retention of underrepresented students from diverse backgrounds especially racial/ethnic minority students and first-generation college students.

Betty Jo Thao was a Masters student in the Department of Educational Policy Studies.

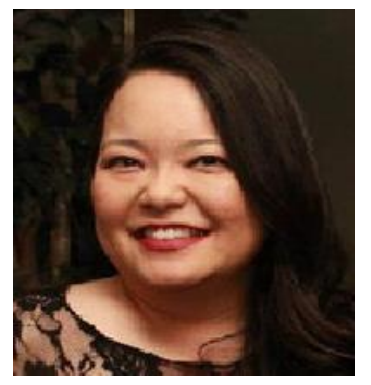

Linda Kue Aroonsavath is a doctoral candidate in the Department of Counseling Psychology at the University of Wisconsin-Madison. Her professional interests are in the educational experiences and career development of racial ethnic minority college students.

Desiree Cabinte is a licensed psychologist at the Department of Veteran Affairs at Pacific Islands Health Care System. 


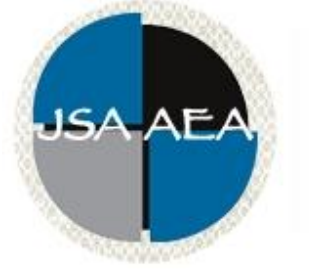

Vol. 12 Iss. 1 (2017)

\title{
Journal of Southeast Asian American Education and Advancement
}

WWW.JSAAEA.org

Editor

Dr. Wayne E. Wright

Purdue University

Associate Editors

Dr. Chhany Sak-Humphry

University of Hawaii at Manoa

Dr. Phitsamay Sychitkokhong Uy

University of Massachusetts, Lowell

\author{
Book Review Editor \\ Dr. Vichet Chhuon \\ University of Minnesota \\ Creative Works Editor \\ Bryan Thao Worra \\ Lao Assistance Center \\ Journal Manager \\ Sung Ae Kim \\ Purdue University
}

\section{Editorial Review Board}

Dr. Steve Arounsack

California State University, Stanislaus

Dr. Sovicheth Boun

The State University of New York, Fredonia

Dr. George Chigas

University of Massachusetts, Lowell

Dr. Hien Duc Do

San Jose State University

Dr. Sophal Ear

Occidental College
Dr. Carl L. Bankston III

Tulane University

Dr. Angela Reyes

Hunter College, The City University of New York

Dr. Loan Dao

University of Massachusetts, Boston

Dr. Changming Duan

University of Missouri, Kansas City

Dr. Sothy Eng

Lehigh University 
Dr. Virak Chan

University of Texas at San Antonio

Dr. Jeremy Hein

University of Wisconsin, Eau Claire

Dr. Nancy H. Hornberger

University of Pennsylvania

Dr. Peter Nien-Chu Kiang

University of Massachusetts, Boston

Dr. Ha Lam

Eastern Mennonite University

Dr. Jonathan H. X. Lee

San Francisco State University

Dr. Monirith Ly

Royal University of Phnom Penh

Dr. Bic Ngo

University of Minnesota

Dr. Leakhena Nou

California State University, Long Beach

Dr. Mark Pfeifer

SUNY Institute of Technology

Dr. Loan T. Phan

University of New Hampshire

Dr. Kalyani Rai

University of Wisconsin, Milwaukee

Dr. Cathy J. Schlund-Vials

University of Connecticut, Storrs

Dr. Nancy J. Smith-Hefner

Boston University

Dr. Yer J. Thao

Portland State University

Dr. Monica M. Trieu

Purdue University

Dr. Silvy Un

Saint Paul Public Schools

Dr. Terrence G. Wiley

Center for Applied Linguistics
Dr. Zha Blong Xiong

University of Minnesota

Dr. Vincent K. Her

University of Wisconsin, Eau Claire

Dr. Peter Tan Keo

New York University

Dr. Kevin K. Kumashiro

University of San Francisco

Dr. Ravy Lao

California State University, Los Angeles

Dr. Stacey Lee

University of Wisconsin, Madison

Dr. Sue Needham

California State University, Dominguez Hills

Dr. Max Niedzwiecki

Daylight Consulting Group

Dr. Clara Park

California State University, Northridge

Dr. Giang Pham

University of Massachusetts

Dr. Karen Quintiliani

California State University, Long Beach

Dr. Phala Chea

Lowell Public Schools

Dr. Fay Shin

California State University, Long Beach

Dr. Christine Su

Ohio University

Dr. Alisia Tran

Arizona State University

Dr. Khatharya Um

University of California, Berkeley

Dr. Linda Trinh Vo

University of California, Irvine

Dr. Yang Sao Xiong

University of Wisconsin-Madison

\section{Doctoral Student Editorial Review Board}

\author{
Anna H. Yang \\ University of Georgia \\ Annie BichLoan Duong \\ San Joaquin County Office of Education \\ Hoa Nha Nguyen \\ Boston College
}

\author{
Keo Chea-Young \\ University of Pennsylvania \\ Dung Minh Mao \\ University of Minnesota \\ Thien-Huong Ninh \\ University of Southern California
}




\section{Malaphone Phommasa \\ Marshall University \\ Molly Wiebie}

The University of Texas at Austin
Krissyvan Truong Claremont Graduate University Soua Xiong

San Diego State University \& Claremont Graduate University 